\title{
Full contents
}

Main authors and contributors $\quad$ x

Preface xiii

1 Corporate venturing in health care: a CbusineZ case 1

Parent and subsidiary $\quad 2$

$\begin{array}{ll}\text { Caring about health care } & 4\end{array}$

The venture process at CbusineZ $\quad 6$

$\begin{array}{ll}\text { Psy Health Direct: a business case } & 7\end{array}$

$\begin{array}{ll}\text { Evolution } & 10\end{array}$

Four operational elements in the venture process $\quad 12$

$\begin{array}{ll}\text { Advancing insights } & 19\end{array}$

$\begin{array}{ll}\text { Everybody wins } & 20\end{array}$

2 Corporate venturing in the chemical industry: a colourful case 22

$\begin{array}{ll}\text { The seed of an idea } & 22\end{array}$

AkzoNobel 23

AkzoNobel New Ventures $\quad 24$

Business unit Pulp \& Paper: a new venture $\quad 26$

$\begin{array}{ll}\text { Practical lessons } & 27\end{array}$

The end of AkzoNobel New Ventures $\quad 28$

A new beginning $\quad 29$

Form plus content $\quad 31$

Four operational elements in the venture process 32

$\begin{array}{ll}\text { Initial success } & 40\end{array}$

3 BAC BV: the successful exit of a Unilever spin-out 41

Unilever Ventures $\quad 42$

BAC BV: a Unilever Ventures spin-out 43

From spin-out to exit $\quad 46$

Four operational elements in the venture process $\quad 48$

How to breed success $\quad 51$

4 Document Services Valley: a lifeline for the printing industry? 52

Innovation at Océ $\quad 53$

Document Services Valley $\quad 54$ 
Structure and organization $\quad 55$

QBengo: find and be found $\quad 56$

Four operational elements in the venture process $\quad 58$

The next stage for Document Services Valley 65

5 Innovation projects and venturing at Rabobank: creating a new $\begin{array}{ll}\text { dynamic } & 67\end{array}$

Structure and organization $\quad 68$

$\begin{array}{ll}\text { MyOrder } & 70\end{array}$

Four operational elements in the venture process $\quad 73$

$\begin{array}{ll}\text { New dynamic } & 79\end{array}$

6 Eindhoven University of Technology's InnovationLab:

commercializing scientific research for scientific research itself $\quad 80$

$\begin{array}{ll}\text { The birth of TU/e InnovationLab } & 81\end{array}$

$\begin{array}{ll}\text { Spin-offs } & 82\end{array}$

$\begin{array}{ll}\text { Synerscope } & 83\end{array}$

Four operational elements in the venture process $\quad 87$

The future of the TU/e InnovationLab 92

7 SanomaVentures: innovating by attracting entrepreneurial talent

Innovation at Sanoma $\quad 94$

Strategic goals $\quad 95$

VirtuaGym: a Sanoma venture $\quad 95$

Four operational elements in the venture process 98

$\begin{array}{ll}\text { The future } & 102\end{array}$

8 nrc.next: reinventing printed news $\quad 105$

NRC Handelsblad and PCM Uitgevers 106

A need to innovate: but how? $\quad 108$

From experimentation to innovation $\quad 109$

NRC 'Miffy' $\quad 112$

A new editorial board $\quad 113$

The run-up and the launch 114

Handelsblad and next: two peas in a pod? $\quad 116$

Four operational elements in the venture process 116

$\begin{array}{ll}\text { What's next? } & 119\end{array}$

9 Discussion and conclusions $\quad 120$

Use of a model $\quad 121$

$\begin{array}{ll}\text { Portfolio } & 123\end{array}$ 
Team composition

Relationship to the parent company

10 Top ten best practices for managing corporate ventures

129

1 Team, team, team

129

2 Physical/organizational separation 130

3 Alignment and top management commitment 130

4 Building a healthy portfolio $\quad 130$

5 Benefiting from partnerships 131

6 Performance rewards and bonuses tied to goals 131

7 Speed is king 131

8 Use of stage-gate processes 131

9 Think small, act big $\quad 132$

10 Capture your experiences 132

References 133

$\begin{array}{ll}\text { Index } & 134\end{array}$ 